\title{
Enhancing the organic production of kohlrabi using algae extract and biofertilizers
}

\author{
Saad Abou-El-Hassan 1, Emad Abdel Aziz Salem 2, ${ }^{*}$, Heba Said El-Batran ${ }^{3}$ and Maged Abdel Aziz El-Nemr ${ }^{3}$ \\ ${ }^{1}$ Central Lab of Organic Agriculture, Agricultural Research Center, Gameat Al-kahera St., Giza, Egypt. \\ ${ }^{2}$ Central Laboratory for Agricultural Climate, Agricultural Research Center, Giza, Egypt. \\ ${ }^{3}$ Agricultural and Biological Division, National Research Center, El-Tahreer St., Giza, Egypt.
}

Publication history: Received on 27 October 2020; revised on 09 November 2020; accepted on 11 November 2020

Article DOI: https://doi.org/10.30574/gscarr.2020.5.2.0093

\begin{abstract}
An experiment aims to improve the organic production of kohlrabi using algae extract and biofertilizer was conducted at the experimental farm of Central Laboratory for Agricultural Climate, Agricultural Research Center, Giza, Egypt, during two successive seasons of 2018/2019 and 2019/2020. Treatments were compost only, compost with adding biofertilizer and algae extract individually or in combination, and were applied on two kohlrabi cultivars (Gulie White Vienna and Delikatess Purple Vienna). The results indicated that "Gulie White Vienna" cultivar was superior to "Delikatess Purple Vienna" in vegetative growth, nutrition content, knob yield and knob properties. All treatments of biofertilizer and algae extract individually or in combination in the presence of compost improved all studied traits compared to compost only. Applying compost with adding biofertilizer and algae extract in combination recorded the highest values of growth, nutrition content, yield and knob properties. This study demonstrated the possibility of using biofertilizer and algae extract in addition to compost for organic production of kohlrabi and for improving yield and knobs quality.
\end{abstract}

Keywords: Kohlrabi; Organic Production; Compost; Biofertilizer; Algae Extract

\section{Introduction}

Kohlrabi (Brassica oleraceavar. Gongylodes L.) is untraditional vegetable crop, belongs to Brassicaceae family and grows in the cool season. It can be planted with seeds, but transplants are preferred, especially for the early marketing [3]. Kohlrabi is mainly cultivated for its enlarged stem (knob) as a marketable and edible portion. These knobs have enormous nutritional and medicinal values due to its high contents of vitamins ( $, B, C$ and $E)$, minerals $(K, C a, M g$ and $\mathrm{Zn)}$ and antioxidant substances that prevent the formation of carcinogens [5]. In Egypt, kohlrabi is still cultivated in very limited areas, besides the total cultivated area and production are unspecified [18]. Kohlrabi is a promising and profitable crop for vegetable growers due to the short growing season and its increasing demand in Europe. This will encourage the expansion of kohlrabi cultivation in Egypt for export due to the gap between demand and production in European countries [17].

Recently, global attention has grown to reduce the effects of environmental pollution and preserve human health, by limiting the use of chemicals in crop production, especially fresh eaten vegetables. Organic farming is one of the methods used to produce healthy vegetables without polluting the ecosystem [27]. So there is an increasing global demand for organic products in the world. The total organic area in the world is 57.8 million hectares, whereas in Egypt is about 105.9 thousand hectares [8]. Organic farming depends on compost as a major source of crop nutrition. Compost is usually added before planting; beside compost is a slow-release fertilizer, which leads to the available nutrients from

${ }^{*}$ Corresponding author: Emad A. Salem

Central Laboratory for Agricultural Climate, Agricultural Research Center, Giza, Egypt. 
compost are not sufficient for nutritional crop requirements, especially short-season vegetables. As a result, most organic vegetables need to add stimulants or supplements during the growing season for improving growth and yield properties [1,9]. Hence, the aim of our research was to evaluate the improvement of organic production of kohlrabi using algae extract and biofertilizer as stimulants environment friendly and inexpensive.

Algae extract is a rich of macro and micro nutrients, nature growth regulators (auxins, gibberellins and cytokinins) that enhance cell division and cell enlargement; this lead to balance of physiological and biological processes; consequently increasing photosynthesis processes and improving growth characters [10]. Algae extract also contain some polyamines and vitamins applied to improve nutritional status [14]. Application of algae extract produced plants with vigor growth, more nutrient uptake, better in the yield and quality $[11,19,21]$. Thus, treating kohlrabi plants with algae extract could be stimulated root establishment, root elongation, enhancement the vegetative growth and yield [13].

Biofertilizer is a substance including some benefit microorganisms, when applied to seeds, seedlings or soil, colonize the rhizosphere zone and promoting growth by increasing the availability of nutrients to the treated plants [25]. Application of N-fixing bacteria (Azotobacter and Azospirillum) in non-leguminous vegetable crops has been of much significance for fixing atmospheric nitrogen and synthesis of biologically growth promoting substances, while phosphate solubilizing and potassium releasing bacteria (Bacillus megaterium and Bacillus circulans, respectively) are important in releasing available phosphorus and potassium by colonizing the root surfaces of growing plants. These biofertilizer also improve the plant growth due to increase in nutrient uptake particularly $\mathrm{P}, \mathrm{K}$ and micro-nutrients, production of growth promoting substances and resistance to plant pathogen $[25,19]$.

Many investigates showed that the combination of biofertilizers with organic fertilizers enhanced the growth, yield and quality of plants such as Kumawat [12] on cabbage, Shams [20] on kohlrabi, Shedeed et al. [22], Singh et al. [23] on onion, Shams and Morsy [21] on broccoli. The objective of this work was to evaluate effectiveness of algae extract and biofertilizer in improving the organic production of kohlrabi.

\section{Material and methods}

\subsection{Experimental Location}

The experiment was conducted at the experimental farm of Central Laboratory for Agricultural Climate (CLAC), Agricultural Research Center, Giza, Egypt, during two successive seasons of 2018/2019 and 2019/2020.

\subsection{Plant Material}

Seeds of kohlrabi (cv. Gulie White Vienna and Delikatess Purple Vienna) were sown in the nursery using foam trays on the third week of September in 2018 and 2019 seasons. Kohlrabi plants were transplanted into soil on the first week of November during both seasons. The experimental soil was analyzed according to FAO [7] and showed in Table 1. Weather data in the experimental region as air temperature and relative humidity (RH \%) were recorded by the meteorological station of CLAC during two growing seasons and the data are presented in Table 2.

Table 1 Physical and chemical properties of the experimental soil

\begin{tabular}{|c|c|c|c|c|c|c|c|c|c|c|c|c|c|}
\hline \multirow{2}{*}{$\begin{array}{l}\text { Sand } \\
\%\end{array}$} & \multirow{2}{*}{$\begin{array}{l}\text { Silt } \\
\%\end{array}$} & \multirow{2}{*}{$\begin{array}{l}\text { Clay } \\
\%\end{array}$} & \multirow{2}{*}{ Texture } & \multirow{2}{*}{ pH } & \multirow{2}{*}{$\begin{array}{l}\text { EC } \\
\mathrm{dS} / \mathrm{m}\end{array}$} & \multicolumn{4}{|c|}{ Cations meq/l } & \multicolumn{4}{|c|}{ Anions meq/l } \\
\hline & & & & & & $\mathrm{Ca}^{+}$ & 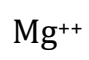 & $\mathrm{K}^{+}$ & $\mathrm{Na}^{+}$ & $03=$ & $\mathrm{O}_{3}^{-}$ & $\mathrm{Cl}^{-}$ & $\mathrm{SO} 4=$ \\
\hline 20. & 40.74 & 48 & & 7.83 & 1. & 2.2 & 10 & 1.6 & 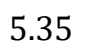 & - & 5.0 & 5.23 & 2.8 \\
\hline
\end{tabular}

\subsection{Experimental Plan}

Experimental soil was divided into ridges (60 cm width). The plants were transplanted at a distance of $15 \mathrm{~cm}$ on one side of ridge and irrigated using the drip system. The plot area was $6 \mathrm{~m}^{2}$ ( $3 \mathrm{~m}$ length and $2 \mathrm{~m}$ width). Each plot included 3 ridges. The treatments included two kohlrabi cultivars (Gulie White Vienna and Delikatess Purple Vienna) and four fertilizer treatments as follow:

Compost (C) only as a control treatment

Compost + biofertilizer $(\mathrm{C}+\mathrm{Bio})$

Compost + algae extract $(\mathrm{C}+$ Algae $)$

Compost + biofertilizer + algae extract $(\mathrm{C}+\mathrm{Bio}+$ Algae $)$. 
The treatments were arranged in a split plot design with three replicates; the two cultivars of kohlrabi were distributed in the main plots and the four fertilizer treatments were randomly arranged in the sub plots.

Table 2 Weekly average of air temperature and relative humidity in Dokki region during growing seasons

\begin{tabular}{|c|c|c|c|c|c|c|c|c|c|c|c|c|c|}
\hline \multirow{3}{*}{ Months } & \multirow{3}{*}{ Weeks } & \multicolumn{6}{|c|}{ First season $(2018 / 2019)$} & \multicolumn{6}{|c|}{ Second season $(2019 / 2020)$} \\
\hline & & & \multicolumn{2}{|c|}{ temperature } & \multicolumn{3}{|c|}{$\begin{array}{l}\text { Relative humidity } \\
{[\%]}\end{array}$} & \multicolumn{3}{|c|}{$\begin{array}{ll}\text { Air } & \text { temperature } \\
{\left[{ }^{\circ} \mathrm{C}\right]} & \end{array}$} & \multicolumn{3}{|c|}{$\begin{array}{l}\text { Relative humidity } \\
{[\%]}\end{array}$} \\
\hline & & & $\max$ & $\min$ & aver & $\max$ & $\min$ & aver & $\max$ & $\min$ & aver & $\max$ & $\min$ \\
\hline \multirow{4}{*}{ Nov. } & $1^{\text {st }}$ & 22.3 & 28.1 & 16.0 & 58.7 & 87.1 & 32.3 & 23.6 & 29.2 & 17.4 & 60.4 & 85.1 & 35.7 \\
\hline & $2^{\mathrm{ed}}$ & 19.9 & 25.6 & 14.8 & 65.0 & 88.6 & 41.3 & 23.7 & 29.6 & 18.8 & 64.0 & 90./ & 37.3 \\
\hline & $3^{\text {rd }}$ & 19.8 & 26.2 & 14.1 & 66.7 & 91.3 & 38.3 & 19.6 & 25.3 & 13.7 & 52.4 & 77.4 & 27.4 \\
\hline & $4^{\text {th }}$ & 18.7 & 24.7 & 13.7 & 65.5 & 88.7 & 37.7 & 19.5 & 25.6 & 13.4 & 54.6 & 78.8 & 30.4 \\
\hline \multirow{4}{*}{ Dec. } & $1^{\text {st }}$ & 16.6 & 22.3 & 12.5 & 66.5 & 87.6 & 43.9 & 18.3 & 22.7 & 12.9 & 64.8 & 85.2 & 44.3 \\
\hline & $2^{\mathrm{ed}}$ & 16.1 & 22.2 & 10.6 & 62.1 & 84.6 & 38.8 & 16.4 & 21.3 & 12.5 & 56.4 & 77.3 & 35.5 \\
\hline & $3^{\text {rd }}$ & 15.2 & 19.9 & 11.1 & 65.3 & 82.2 & 48.5 & 15.7 & 21.1 & 10.1 & 70.4 & 93.5 & 47.3 \\
\hline & $4^{\text {th }}$ & 14.9 & 20.6 & 10.5 & 66.6 & 86.9 & 43.3 & 15.2 & 20.3 & 11.2 & 51.0 & 67.6 & 34.3 \\
\hline \multirow{2}{*}{ Jan. } & $1^{\text {st }}$ & 13.0 & 20.8 & 7.6 & 60.8 & 87.1 & 33.1 & 13.9 & 18.7 & 9.3 & 65.3 & 80.2 & 50.4 \\
\hline & $2^{e d}$ & 14.4 & 25.3 & 3.5 & 59.2 & 94.0 & 24.4 & 13.6 & 22.6 & 4.6 & 58.4 & 93.2 & 23.6 \\
\hline
\end{tabular}

\subsection{Method of Applications}

The quantity of compost was calculated based on nitrogen requirement for kohlrabi plants (70 kg/ feddan); meaning 70 tons compost/feddan (feddan $=0.42$ hectare) was added at once during soil preparation. Chemical analysis of the used compost was presented in Table 3. Biofertilizer (SWERI) is a commercial biofertilizer produced by Soil, Water and Environment Research Institute. It contains of mixture of $\mathrm{N}$ fixing bacteria (Azotobacter chroococcum and Azospirillium brasilense), $\mathrm{P}$ solubilizing bacteria (Bacillus megaterium) and potassium releasing bacteria (Bacillus circulans) loaded with vermiculite substrate.

Fresh algae (Spirulina platensis) were obtained from Soil, Water and Environment Research Institute, Agricultural Research Center. Algae extract was prepared by grinding fresh algae in a blender, after diluted with water at rate $50 \%$ and refrigerated on $0-4 \stackrel{\circ}{\circ}$ until use according to Pise and Sabale [15]. The algae extract was diluted with water at rate $0.5 \%$ and filtered through a double layer of muslin before use immediately. Chemical composition of algae extract is illustrated in Table 4. Biofertilizer (SWERI) was added twice, the first as a seed coating at rate $4 \mathrm{~g} / 100 \mathrm{~g}$ before sowing seeds in the foam trays, the second as a soil inoculation at rate $1 \mathrm{~kg} /$ feddan before transplanting directly. Algae extract was applied as soil addition at three times after 1, 3 and 5 weeks from transplanting at rate $10 \mathrm{l} /$ feddan.

Table 3 Chemical Analysis of the used compost

\begin{tabular}{|c|c|c|c|c|c|c|c|c|c|c|c|c|}
\hline \multirow{2}{*}{ pH } & \multirow{2}{*}{$\begin{array}{c}\text { EC } \\
\end{array}$} & $\mathbf{0 . C}$ & $\mathbf{0 . M}$ & \multicolumn{4}{|c|}{ Macro elements (\%) } & \multicolumn{4}{|c|}{ Micro elements(ppm) } \\
\cline { 5 - 13 } & $\mathbf{d S} / \mathbf{m}$ & $\mathbf{( \% )}$ & $\mathbf{( \% )}$ & $\mathrm{N}$ & $\mathrm{P}$ & $\mathrm{K}$ & $\mathrm{Ca}$ & $\mathrm{Mg}$ & $\mathrm{Fe}$ & $\mathrm{Zn}$ & $\mathrm{Mn}$ & $\mathrm{Cu}$ \\
\hline 7.12 & 3.69 & 17.15 & 28.13 & 0.98 & 0.74 & 0.92 & 0.34 & 0.62 & 624 & 78 & 126 & 13 \\
\hline
\end{tabular}

Table 4 Chemical composition of algae extract

\begin{tabular}{|c|c|c|c|c|c|c|c|c|}
\hline \multicolumn{4}{|c|}{ Macro elements (\%) } & \multicolumn{4}{c|}{ Micro elements(ppm) } \\
\hline $\mathrm{N}$ & $\mathrm{P}$ & $\mathrm{K}$ & $\mathrm{Ca}$ & $\mathrm{Mg}$ & $\mathrm{Fe}$ & $\mathrm{Zn}$ & $\mathrm{Mn}$ & $\mathrm{Cu}$ \\
\hline 4.38 & 0.64 & 2.18 & 0.67 & 0.92 & 264 & 58 & 55 & 6 \\
\hline
\end{tabular}




\subsection{Data Recorded}

At harvest after 10 weeks from transplanting, six plants from each plot were randomly tagged to evaluate the following parameters; plant height, number of leaves and plant fresh weight. Nutrient contents (N, P and K) in kohlrabi plants were determined in the inner mature leaf [4]. As well as, average weight of knob, knob diameter, knob firmness and total yield/plot were measured. Height of plants was measured from soil level to the apex of the longest leaf. Total nitrogen, phosphorus and potassium were determined in the digested leaves according to [7]; nitrogen by Kjeldahl, phosphorus by spectrophotometer and potassium was determined photometrically using flame photometer. On the basis of knob yield/plot after removing leaves the yield/feddan was estimated. Knob weight was recorded after removing leaves. Knob diameter was measured by vernier caliper at maximum growth portion. Knob firmness was measured by Pressure Tester (1.5 mm diameter).

\subsection{Statistical Analysis}

Data were statistically analyzed by the analysis of variance according to [24] by SAS software, version 2004. Treatment means were compared using Tukey test at 5\% level of probability.

\section{Results and discussion}

\subsection{Growth parameters}

The growth parameters of tow kohlrabi cultivars under different fertilizer treatments were presented in Table 5. Data in both seasons revealed that, Gulie White Vienna cultivar recorded the highest values of all growth parameters compared to Delikatess Purple Vienna cultivar. The differences in vegetative growth parameters between cultivars might be related to the genetic make-up for each cultivar. These results are in good agreement with those mentioned by [6].

Table 5 Response of growth parameters of kohlrabi cultivars to different treatments in both seasons

\begin{tabular}{|c|c|c|c|c|c|c|c|}
\hline \multirow{3}{*}{$\begin{array}{l}\text { Fertilizer } \\
\text { treatments }\end{array}$} & \multicolumn{3}{|c|}{$2018 / 2019$ season } & \multicolumn{4}{|c|}{$2018 / 2019$ season } \\
\hline & \multicolumn{7}{|c|}{ Cultivars } \\
\hline & $\begin{array}{c}\text { Gulie White } \\
\text { Vienna }\end{array}$ & $\begin{array}{c}\text { Delikatess } \\
\text { Purple } \\
\text { Vienna }\end{array}$ & Mean & $\begin{array}{c}\text { Gulie White } \\
\text { Vienna }\end{array}$ & $\begin{array}{c}\text { Delikatess } \\
\text { Purple } \\
\text { Vienna }\end{array}$ & \multicolumn{2}{|l|}{ Mean } \\
\hline & \multicolumn{7}{|c|}{ Plant height $(\mathrm{cm})$} \\
\hline Compost & $39.44 \mathrm{de}$ & $36.47 \mathrm{e}$ & $37.96 \mathrm{C}$ & $43.11 \mathrm{de}$ & $39.20 \mathrm{e}$ & $41.16 \mathrm{C}$ & $\mathrm{C}$ \\
\hline $\mathrm{C}+\mathrm{Bio}$ & $46.11 \mathrm{bc}$ & $42.33 \mathrm{~cd}$ & $44.22 \mathrm{~B}$ & $50.50 \mathrm{~b}$ & $45.59 \mathrm{~cd}$ & $48.04 \quad \mathrm{~B}$ & B \\
\hline $\mathrm{C}+$ Algae & $45.11 \mathrm{bc}$ & $40.67 \mathrm{~d}$ & $42.89 \mathrm{~B}$ & $49.31 \mathrm{bc}$ & $43.73 \mathrm{~d}$ & $46.52 \quad \mathrm{~B}$ & B \\
\hline $\mathrm{C}+\mathrm{Bio}+$ Algae & $51.89 \mathrm{a}$ & $47.33 \mathrm{~b}$ & $49.61 \mathrm{~A}$ & $55.67 \mathrm{a}$ & $50.99 \mathrm{~b}$ & $53.33 \quad A$ & A \\
\hline \multirow[t]{2}{*}{ Mean } & $45.64 \quad \mathrm{~A}$ & $41.70 \quad \mathrm{~B}$ & & $49.65 \quad \mathrm{~A}$ & $44.88 \quad \mathrm{~B}$ & & \\
\hline & \multicolumn{7}{|c|}{ Leaf number/plant } \\
\hline Compost & $10.33 \mathrm{~cd}$ & $8.67 \mathrm{e}$ & $9.50 \mathrm{D}$ & $10.67 \mathrm{~cd}$ & $9.00 \mathrm{e}$ & $9.83 \quad \mathrm{D}$ & $\mathrm{D}$ \\
\hline $\mathrm{C}+\mathrm{Bio}$ & $12.00 \mathrm{~b}$ & $11.00 \mathrm{bcd}$ & $11.50 \quad \mathrm{~B}$ & $12.33 \mathrm{~b}$ & $11.33 \mathrm{bc}$ & $11.83 \mathrm{~B}$ & B \\
\hline $\mathrm{C}+$ Algae & $11.33 \mathrm{bc}$ & $10.00 \mathrm{~d}$ & $10.67 \mathrm{C}$ & $11.67 \mathrm{bc}$ & $10.00 \mathrm{de}$ & 10.83 & $\mathrm{C}$ \\
\hline $\mathrm{C}+\mathrm{Bio}+\mathrm{Algae}$ & $13.67 \quad \mathrm{a}$ & $12.00 \mathrm{~b}$ & $12.83 \mathrm{~A}$ & $14.00 \mathrm{a}$ & $12.33 \mathrm{~b}$ & $13.17 \quad A$ & A \\
\hline \multirow[t]{2}{*}{ Mean } & $11.83 \mathrm{~A}$ & $10.42 \mathrm{~B}$ & & $12.17 \quad \mathrm{~A}$ & $10.67 \quad \mathrm{~B}$ & & \\
\hline & \multicolumn{7}{|c|}{ Plant fresh weight (g) } \\
\hline Compost & $307.3 \mathrm{e}$ & $281.0 \mathrm{e}$ & $294.7 \quad \mathrm{D}$ & $337.3 \mathrm{f}$ & $303.7 \mathrm{~g}$ & 320.3 & \\
\hline $\mathrm{C}+\mathrm{Bio}$ & 391.7 bc & $374.7 \mathrm{~cd}$ & $383.3 \quad \mathrm{~B}$ & 429.3 bc & $404.3 \mathrm{~cd}$ & 417.0 & $\mathrm{~B}$ \\
\hline $\mathrm{C}+$ Algae & $363.3 \mathrm{~cd}$ & $342.3 \mathrm{~d}$ & $353.0 \mathrm{C}$ & $397.0 \mathrm{de}$ & 367.3 ef & 382.3 & $\mathrm{C}$ \\
\hline $\mathrm{C}+\mathrm{Bio}+$ Algae & $445.0 \quad \mathrm{a}$ & $408.7 \quad b$ & $426.0 \quad \mathrm{~A}$ & $481.7 \quad \mathrm{a}$ & $440.3 \mathrm{~b}$ & 461.0 & $\mathrm{~A}$ \\
\hline Mean & $376.3 \mathrm{~A}$ & $351.7 \quad \mathrm{~B}$ & & $411.7 \quad \mathrm{~A}$ & $379.0 \mathrm{~B}$ & & \\
\hline
\end{tabular}

Fertilizer treatments showed significant differences of growth parameters. Where, application of compost + biofertilizer + algae extract gave the highest values of height, leaf number and fresh weight for kohlrabi plants. On the other hand, application of compost only recorded the lowest values of these parameters. Whereas, the plants treated with compost 
+ biofertilizer or compost + algae extract were moderate. Improvement in the growth of kohlrabi plants with using compost + biofertilizer + algae extract might be due to add biofertilizer in the presence of compost increased the mass of beneficial microorganisms in the soil, which increased their efficiency in improving the growth of plants by production of growth promoting compounds and releasing of many nutrients found in the compost, as well as fixing $\mathrm{N}$ atmospheric in a form available for absorption by plant roots $[25,12,16,20]$. Besides, the role of algae extract, which contains an adequate amount of nutrients and growth regulators that enhance cell division and cell enlargement [10,13]. All these benefits have been reflected in improving vegetative growth of plants.

The interaction of different fertilizer applications and cultivars had significant effect on growth parameters in both seasons. The highest values of all growth parameters were recorded by treatment of compost + biofertilizer + algae extract with Gulie White Vienna cultivar. While the lowest values of all growth parameters were recorded using compost only with Delikatess Purple Vienna cultivar.

\subsection{Nutritional status}

The nutritional status of two kohlrabi cultivars under different fertilizer treatments are shown in Table 6. Results in both seasons indicated that Gulie White Vienna cultivar was higher than Delikatess Purple Vienna cultivar in N, P and K contents of kohlrabi leaves. This might due to the differences between genotypes in the efficiency of utilization of different nutrients [26].

Table 6 Response of nutritional status of kohlrabi cultivars to different treatments in both seasons

\begin{tabular}{|c|c|c|c|c|c|c|c|}
\hline \multirow{3}{*}{$\begin{array}{l}\text { Fertilizer } \\
\text { treatments }\end{array}$} & \multicolumn{4}{|c|}{$2018 / 2019$ season } & \multicolumn{3}{|c|}{$2018 / 2019$ season } \\
\hline & \multicolumn{7}{|c|}{ Cultivars } \\
\hline & $\begin{array}{c}\text { Gulie White } \\
\text { Vienna }\end{array}$ & $\begin{array}{c}\text { Delikatess } \\
\text { Purple } \\
\text { Vienna } \\
\end{array}$ & \multicolumn{2}{|l|}{ Mean } & $\begin{array}{c}\text { Gulie White } \\
\text { Vienna }\end{array}$ & $\begin{array}{c}\text { Delikatess } \\
\text { Purple } \\
\text { Vienna } \\
\end{array}$ & Mean \\
\hline & \multicolumn{7}{|c|}{$\mathrm{N}(\%)$} \\
\hline Compost & $2.187 \mathrm{e}$ & $2.037 \mathrm{e}$ & 2.112 & $\mathrm{D}$ & $2.373 \mathrm{e}$ & $2.193 \mathrm{e}$ & 2.282 \\
\hline $\mathrm{C}+$ Bio & $3.090 \mathrm{~b}$ & $2.767 \quad \mathrm{c}$ & 2.927 & $\mathrm{~B}$ & $3.353 \mathrm{~b}$ & $2.980 \quad \mathrm{c}$ & 3.167 \\
\hline $\mathrm{C}+$ Algae & $2.793 \mathrm{c}$ & $2.503 \mathrm{~d}$ & 2.647 & $\mathrm{C}$ & $3.023 \mathrm{c}$ & $2.690 \mathrm{~d}$ & 2.857 \\
\hline $\mathrm{C}+\mathrm{Bio}+$ Algae & $3.383 \mathrm{a}$ & $3.133 \mathrm{~b}$ & 3.260 & $\mathrm{~A}$ & $3.670 \quad \mathrm{a}$ & $3.380 \mathrm{~b}$ & 3.524 \\
\hline \multirow[t]{2}{*}{ Mean } & $2.862 \mathrm{~A}$ & $2.610 \quad \mathrm{~B}$ & & & $3.105 \mathrm{~A}$ & $2.810 \quad \mathrm{~B}$ & \\
\hline & \multicolumn{7}{|c|}{$\mathrm{P}(\%)$} \\
\hline Compost & $0.237 \mathrm{~d}$ & $0.221 \mathrm{~d}$ & 0.229 & $\mathrm{C}$ & $0.254 \mathrm{e}$ & $0.236 \mathrm{e}$ & 0.245 \\
\hline $\mathrm{C}+\mathrm{Bio}$ & $0.367 \mathrm{~b}$ & 0.346 bc & 0.356 & B & $0.394 \mathrm{bc}$ & $0.369 \mathrm{~cd}$ & 0.382 \\
\hline $\mathrm{C}+$ Algae & $0.350 \mathrm{bc}$ & $0.330 \mathrm{c}$ & 0.340 & B & 0.377 bcd & $0.355 \mathrm{~d}$ & 0.366 \\
\hline $\mathrm{C}+\mathrm{Bio}+$ Algae & $0.400 \quad \mathrm{a}$ & $0.369 \mathrm{~b}$ & 0.384 & $\mathrm{~A}$ & $0.430 \quad \mathrm{a}$ & $0.400 \mathrm{~b}$ & 0.415 \\
\hline \multirow[t]{2}{*}{ Mean } & $0.339 \quad \mathrm{~A}$ & $0.317 \quad \mathrm{~B}$ & & & $0.364 \quad \mathrm{~A}$ & $0.340 \quad \mathrm{~B}$ & \\
\hline & \multicolumn{7}{|c|}{$\mathrm{K}(\%)$} \\
\hline Compost & $1.810 \mathrm{f}$ & $1.697 \mathrm{f}$ & 1.754 & $\mathrm{D}$ & $1.938 \mathrm{f}$ & $1.818 \mathrm{f}$ & 1.878 \\
\hline $\mathrm{C}+\mathrm{Bio}$ & $2.664 \mathrm{c}$ & $2.512 \mathrm{~cd}$ & 2.588 & B & $2.844 \quad \mathrm{c}$ & $2.696 \mathrm{~cd}$ & 2.770 \\
\hline $\mathrm{C}+$ Algae & $2.456 \mathrm{de}$ & $2.320 \mathrm{e}$ & 2.388 & $\mathrm{C}$ & $2.623 \mathrm{de}$ & $2.494 \mathrm{e}$ & 2.558 \\
\hline $\mathrm{C}+\mathrm{Bio}+$ Algae & $3.257 \quad \mathrm{a}$ & $3.052 \mathrm{~b}$ & 3.154 & $\mathrm{~A}$ & $3.507 \quad \mathrm{a}$ & $3.282 \mathrm{~b}$ & 3.395 \\
\hline Mean & $2.547 \quad \mathrm{~A}$ & $2.395 \quad \mathrm{~B}$ & & & $2.728 \quad \mathrm{~A}$ & $2.572 \quad \mathrm{~B}$ & \\
\hline
\end{tabular}

Means followed in same column by similar letters are not statistically different at 0.05 level according to Tukey test. $\mathrm{C}=$ compost; Bio = biofertilizer of Azotobacter chroococcum, Azospirillium brasilense, Bacillus megaterium and Bacillus circulans; Algae = algae extract of Spirulina platensis.

All applications of biofertilizer and algae extract individually or in combination in the presence of compost significant increased $\mathrm{N}, \mathrm{P}$ and $\mathrm{K}$ contents of kohlrabi leaves compared to compost only. Treatment of compost with adding biofertilizer and algae extract in combination gave the highest contents of N, P and K in leaves. High contents of N, P and $\mathrm{K}$ in plant leaves treated with compost + biofertilizer + algae extract could be explained by the positive role of algae 
extract and biofertilizer. Where, algae extract is rich in macro and micro nutrients, it also contain some polyamines and vitamins applied to improve nutritional status [14]. Besides, the role of biofertilizer, which is fixing atmospheric nitrogen and releasing of essential nutrients found in the compost to be available for plants, where compost is a large store of nutrients in slow release form $[25,16,2]$.

Regarding the interaction between different fertilizers and kohlrabi cultivars, in both seasons, the highest contents of $\mathrm{N}$, P and K in leaves were obtained using compost + biofertilizer + algae extract with Gulie White Vienna cultivar. On the other hand, applying compost only with both cultivars gave the lowest contents of N, P and K in leaves.

\subsection{Kohlrabi yield}

Response of yield of kohlrabi cultivars to different fertilizer treatments in both seasons is presented in Table 7. Data indicated that a significant increase was recorded in the yield of Gulie White Vienna cultivar more than Delikatess Purple Vienna cultivar in both season. This might due to differences among genotypes in their adaptability to the environment conditions and nutrient use efficiency. These results are in harmony with those stated by Yoldas et al., and El-Bassiony et al., [6,26].

Fertilizer treatments showed significant effect on yield of kohlrabi in both season. All treatments of biofertilizer and algae extract individually or in combination in the presence of compost significantly increased yield of kohlrabi compared to compost only. Treatment of compost with adding biofertilizer and algae extract in combination produced the highest yield. Treatment of compost with adding biofertilizer came in the second order, followed by treatment of compost with adding algae extract. The lowest yield was produced with using compost only. Superiority of the yield in kohlrabi plants treated with compost + biofertilizer + algae extract might be attributed to add the biofertilizer in the presence of compost, which led to increased efficiency of microorganisms in production of growth promoters and fixation of nitrogen and releasing essential nutrients in the form available for absorption by plant roots [22,23,24]. Besides, the positive role of algae extract in improving production, as application of algae extract produced plants with vigor growth, more nutrient uptake, better in the yield and quality $[11,13,19,21]$. All these improved of plant nutrition and consequently increased yield of kohlrabi.

The interaction between kohlrabi cultivars and fertilizer treatments had significant effects on yield in both season. Using compost + biofertilizer + algae extract with Gulie White Vienna cultivar produced the highest yield. On the other hand, applying compost only with Delikatess Purple Vienna cultivar produced the lowest yield.

Table 7 Response of yield of kohlrabi cultivars to different fertilizer treatments in both seasons

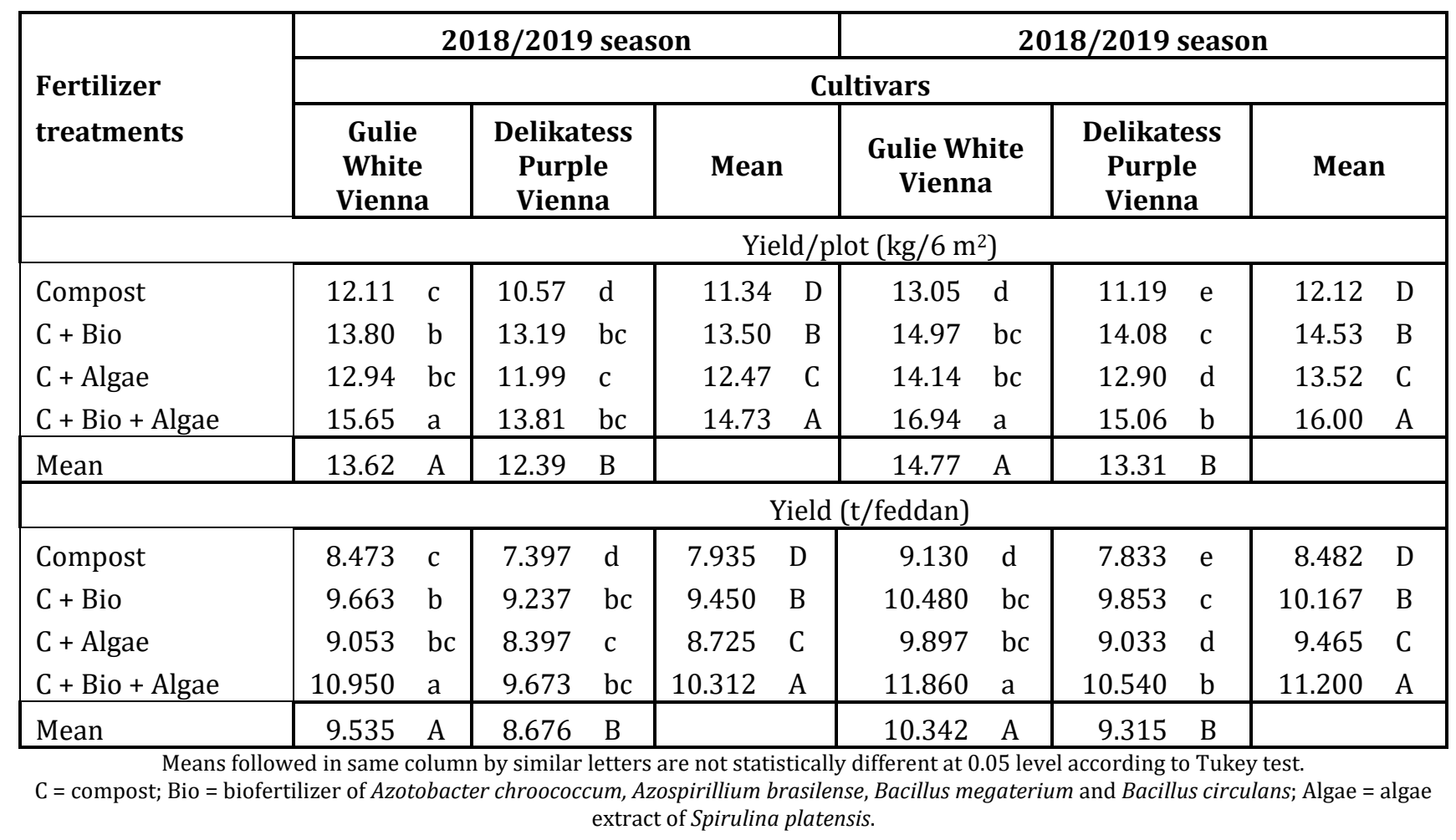




\subsection{Kohlrabi knob properties}

Data in Table 8 show the effects of different fertilizer treatments on knob properties for tow cultivars of kohlrabi in the two seasons. The cultivar of Gulie White Vienna recorded weight and diameter of knob higher than Delikatess Purple Vienna cultivar. This result seems logical due to the superiority of Gulie White Vienna plants in growth parameters and nutritional status (Tables 5 and 6), thus reflected on its superiority in weight and diameter of knob. Meanwhile, there were no significant differences between kohlrabi cultivars in knob firmness.

Effect of different fertilizer treatments on knob properties showed that using compost + biofertilizer + algae extract recorded the highest weight and diameter of knob compared to other treatments. Treatment of compost + biofertilizer came in the second rank, while treatment of compost + algae extract came in the third rank, finally treatment of compost only recorded the lowest weight and diameter of knob. Meanwhile, there were no significant differences among all different fertilizer treatments in knob firmness. The superiority of plants treated with compost + biofertilizer + algae extract in weight and diameter of knob might be attributed to the superiority of these plants in the parameters of growth and nutritional content (Tables 5 and 6 respectively), which was reflected in increasing weight and diameter of knob. These results are in harmony with many literatures [11,19,20,21,22,23].

Table 8 Response of knob properties of kohlrabi cultivars to different fertilizer treatments in both seasons

\begin{tabular}{|c|c|c|c|c|c|c|c|c|}
\hline \multirow{3}{*}{$\begin{array}{l}\text { Fertilizer } \\
\text { treatments }\end{array}$} & \multicolumn{4}{|c|}{$2018 / 2019$ season } & \multicolumn{4}{|c|}{$2018 / 2019$ season } \\
\hline & \multicolumn{8}{|c|}{ Cultivars } \\
\hline & $\begin{array}{c}\text { Gulie } \\
\text { White } \\
\text { Vienna }\end{array}$ & $\begin{array}{c}\text { Delikatess } \\
\text { Purple } \\
\text { Vienna }\end{array}$ & \multicolumn{2}{|l|}{ Mean } & $\begin{array}{c}\text { Gulie White } \\
\text { Vienna }\end{array}$ & $\begin{array}{c}\text { Delikatess } \\
\text { Purple } \\
\text { Vienna }\end{array}$ & \multicolumn{2}{|c|}{ Mean } \\
\hline & \multicolumn{8}{|c|}{ Knob weight (g) } \\
\hline Compost & $214.7 \quad \mathrm{~d}$ & $187.3 \mathrm{e}$ & 201.0 & & $231.3 \mathrm{e}$ & $198.3 \mathrm{f}$ & 214.8 & $\mathrm{D}$ \\
\hline $\mathrm{C}+\mathrm{Bio}$ & 255.7 bc & 244.3 bc & 250.0 & $\mathrm{~B}$ & $277.0 \quad b c$ & $260.7 \mathrm{~cd}$ & 268.8 & $\mathrm{~B}$ \\
\hline $\mathrm{C}+$ Algae & $234.3 \mathrm{~cd}$ & $217.3 \mathrm{~d}$ & 225.8 & $\mathrm{C}$ & $256.0 \mathrm{~d}$ & 233.7 e & 244.8 & $\mathrm{C}$ \\
\hline $\mathrm{C}+\mathrm{Bio}+$ Algae & 296.3 a & $261.7 \quad b$ & 279.0 & $\mathrm{~A}$ & $320.7 \quad a$ & $285.3 \quad b$ & 303.0 & $\mathrm{~A}$ \\
\hline \multirow[t]{2}{*}{ Mean } & $250.3 \quad \mathrm{~A}$ & $227.7 \quad$ B & & & $271.3 \quad \mathrm{~A}$ & $244.5 \quad B$ & & \\
\hline & \multicolumn{8}{|c|}{ Knob diameter $(\mathrm{cm})$} \\
\hline Compost & $6.50 \mathrm{e}$ & $5.73 \mathrm{f}$ & 6.12 & $\mathrm{D}$ & $7.00 \mathrm{e}$ & $6.00 \mathrm{f}$ & 6.50 & $\mathrm{D}$ \\
\hline $\mathrm{C}+\mathrm{Bio}$ & $7.73 \mathrm{~b}$ & $7.37 \quad b c$ & 7.55 & $\mathrm{~B}$ & $8.38 \mathrm{~b}$ & $7.80 \mathrm{~cd}$ & 8.09 & $\mathrm{~B}$ \\
\hline $\mathrm{C}+$ Algae & $7.03 \mathrm{~cd}$ & $6.73 \mathrm{de}$ & 6.88 & $\mathrm{C}$ & $7.70 \mathrm{~cd}$ & $7.27 \mathrm{de}$ & 7.48 & $\mathrm{C}$ \\
\hline $\mathrm{C}+\mathrm{Bio}+$ Algae & $8.80 \quad \mathrm{a}$ & $7.87 \quad b$ & 8.33 & $\mathrm{~A}$ & $9.30 \quad \mathrm{a}$ & $8.50 \mathrm{~b}$ & 8.90 & $\mathrm{~A}$ \\
\hline \multirow[t]{2}{*}{ Mean } & $7.52 \mathrm{~A}$ & $6.93 \mathrm{~B}$ & & & $8.10 \mathrm{~A}$ & $7.39 \quad \mathrm{~B}$ & & \\
\hline & \multicolumn{8}{|c|}{ Knob firmness $\left(\mathrm{kg} / \mathrm{cm}^{2}\right)$} \\
\hline Compost & $14.04 \mathrm{a}$ & $13.96 \mathrm{a}$ & 14.00 & $\mathrm{~A}$ & $13.09 \mathrm{c}$ & $12.98 \quad \mathrm{a}$ & 13.03 & A \\
\hline $\mathrm{C}+\mathrm{Bio}$ & $14.80 \quad \mathrm{a}$ & $14.04 \mathrm{a}$ & 14.42 & A & $14.16 \mathrm{c}$ & $13.11 \quad \mathrm{a}$ & 13.63 & A \\
\hline $\mathrm{C}+$ Algae & $14.77 \quad \mathrm{a}$ & $14.15 \mathrm{a}$ & 14.46 & $\mathrm{~A}$ & $14.09 \mathrm{c}$ & $13.16 \mathrm{a}$ & 13.62 & A \\
\hline $\mathrm{C}+\mathrm{Bio}+$ Algae & $15.00 \quad \mathrm{a}$ & $14.07 \mathrm{a}$ & 14.53 & A & $14.27 \mathrm{c}$ & $12.88 \quad \mathrm{a}$ & 13.57 & $A$ \\
\hline Mean & $14.65 \mathrm{~A}$ & $14.06 \mathrm{~A}$ & & & $13.90 \mathrm{~A}$ & $13.03 \mathrm{~A}$ & & \\
\hline
\end{tabular}

Means followed in same column by similar letters are not statistically different at 0.05 level according to Tukey test.

$\mathrm{C}=$ compost; $\mathrm{Bio}=$ biofertilizer of Azotobacter chroococcum, Azospirillium brasilense, Bacillus megaterium and Bacillus circulans; Algae = algae extract of Spirulina platensis. 
Regarding the interaction between fertilizer treatments and kohlrabi cultivars in both seasons, application of compost + biofertilizer + algae extract with Gulie White Vienna cultivar produced the highest weight and diameter of kohlrabi knob. On contrast, applying compost only with Delikatess Purple Vienna cultivar produced the lowest weight and diameter of kohlrabi knob. The interaction between fertilizer treatments and kohlrabi cultivars did not show any significant effects on knob firmness.

\section{Conclusion}

It could be concluded that the possibility of using algae extract and biofertilizer for improving organic production of kohlrabi cultivars. Gulie White Vienna cultivar was superior to Delikatess Purple Vienna in vegetative growth, nutrition content, knob yield and knob properties. Application of compost with adding biofertilizer and algae extract in combination produced the beast yield and quality of kohlrabi knobs.

\section{Compliance with ethical standards}

\section{Acknowledgments}

This work has been supported by Central Lab of Organic Agriculture, Agricultural Research Center - Central Laboratory for Agricultural Climate, Agricultural Research Center - Agricultural and Biological Division, National Research Center.

\section{Disclosure of conflict of interest}

The authors (Saad Abou-El-Hassan, Emad A. Salem, Heba S. El-Batran and Maged A. El-Nemr) have no conflicts of interest.

\section{References}

[1] Abou-El-Hassan S, Abdrabbo MAA, Desoky AH. Enhancing organic production of cucumber by using plant growth promoting rhizobacteria and compost tea under sandy soil condition. Research Journal of Agric. Biol. Sci., 2014; 10(2): 162-169.

[2] Ahmad R, Shehzad SM, Khalid A, Arshad M, Mahmood MH. Growth and yield response of wheat and maize to nitrogen and L tryptophan enriched compost. Pak. J. Bot., 2008; 39(2): 541-549.

[3] Bieasida A. Effect of flat covers and plant density on yielding and quality of kohlrabi. J. Elemental., 2008; 13(2): 167-173.

[4] Cottenie A, Verloo M, Kiekers L, Velghe G, Camrbynek R. Chem. Anal. Plants Soils. Hand Book. 1982; 1-63, Ghent, Belgium.

[5] Dhaliwal MS. Cole Crops. In: Handbook of Vegetable Crops 3rd ed., chapter 6, Kalyani Publishers; 2017; pp. 148176.

[6] El-Bassiony AM, Fawzy ZF, El-Nemr MA, Li Yunsheng. Improvement of growth, yield and quality of two varieties of kohlrabi plants as affected by application of some bio stimulants. Middle East J. Agri. Res., 2014; 3(3): 491498.

[7] FAO. Guide to laboratory establishment for plant nutrient analysis. Fertilizer and Plant Nutrition Bulletin. 2008; 19.

[8] FiBL and IFOAM. The World of Organic Agriculture, Stati. Emerg. Trend; 2008.

[9] Gross A, Arusi R, Fine P, Nejidat A. Assessment of extraction methods with fowl manure for the production of liquid organic fertilizers. Biores. Technol., 2008; 99(2): 327-334.

[10] Jensen E. Seaweed; fact or fancy. Published by Moses the Midwest Organic and Sustainable Education. From the broad Caster. 2004; 12(3): 164-170.

[11] Khan W, Rayirath UP, Subramanian S, Jithesh MN, Rayorath P, Hodges, DM, Critchley AT, Craigie, JS, Norrie J, Prithiviraj B. Seaweed extracts as biostimulants of plant growth and development. J. Plant Growth Regul., 2009; 28: 386-399.

[12] Kumawat G. Effect of different fertility levels and biofertilizers on growth and yield of cabbage (Brassica oleracea var. capitataL.). M.Sc. (Ag.) Thesis, Submitted to Rajasthan Agricultural University Bikaner, Campus: Jobner; 2009. 
[13] Morsy NM. Productivity and quality of kohlrabi grown in a newly reclaimed sandy soil using organic and mineral$\mathrm{N}$ fertilizer regimes with or without spraying of Spirulina platensis extract. Egypt. J. Hort., 2019; 46(2): 169-178.

[14] Papenfus HB, Kulkarni MG, Stirk WA, Finnie JF, Van Staden J. Effect of commercial seaweed extract (Kelpak) and polyamines on nutrient-deprived (N, P and K) okra seedlings. Sci. Hort., 2013; 151:142-146.

[15] Pise NM, Sabale AB. Effect of seaweed concentrate on the growth and biochemical constituents of Trigonella foenum graecum L. J. Phytol., 2010; 2(4): 50-56.

[16] Saharan BS, Nehra V. Plant growth promoting rhizobacteria: A Critical Review. Life Sci. Medi. Res., $2011 ; 21$.

[17] Saleh SA, Zaki MF, Nagwa Hassan MK, Ezzo MI. Optimizing nitrogen sources and doses for optimum kohlrabi production in new reclaimed lands. J. Appl. Sci., 2013; 9(3): 1642-1650.

[18] Saleh SA, Abo El Hamd ASA, Ahmed ME, Mohamed AA. Effect of planting time and plant spacing on growth, productivity and tuber quality of kohlrabi (Brassica oleracea var gongylodes L). Egypt. J. Appl. Sci., 2010; 25(10b):723-741.

[19] Sarhan TZ, Ali ST, Rasheed SMS. Effect of bread yeast and seaweed extracts on Cucumber (Cucumis sativus L.) plant growth, yield and fruit quality. Mesopotamia J. Agric., 2011; 39(2): 26-34.

[20] Shams AS. Effect of mineral, organic and bio-fertilizers on growth, yield, quality and sensory evaluation of kohlrabi. Res. J. Agric. Biol. Sci., 2012; 8(2): 305-314.

[21] Shams AS, Morsy NM. Nitrogen sources and algae extract as candidates for improving the growth, yield and quality traits of broccoli plants. J. Plant Produc., Mansoura Univ., 2019; 10(5): 399-407.

[22] Shedeed SI, EL-Sayed SAA, Abo Bash DM. Effectiveness of bio-fertilizers with organic matter on the growth, yield and nutrient content of Onion (Allium cepa L.) plants. European Int. J. Sci. Tech., 2014; 3(9): 115-122.

[23] Singh A, Ram RB, Meena ML. Efficacy of different sources of nutrients and biofertilizers on growth yield quality of onion. Int. Res. J. Natural and Appl. Sci., 2015; 2(10): 64-70.

[24] Snedecor GW, Cochran W.G. Statistical methods. Sixth Edition, Iowa state university press, Ames., Iowa, U.S.A; 1980.

[25] Vessey JM. Plant growth promoting rhizobacteria as biofertilizers. Plant Soil, 2003, 255:571-586.

[26] Yoldas F, Ceylan S, Mordogan N, Esetlili BC. Effect of organic and inorganic fertilizers on yield and mineral content of onion (Allium cepa L.). Afri. J. Biotech., 2011; 10(55): 11488-11492.

[27] Zhang QY, Chen Y, Jilani G, Shamsi IH, Yu Q. Model Avswat Apropos of simulating non-point source pollution in Taihu lake basin. J. Haz. Mat., 2010; 174: 824-830. 